\title{
PENINGKATAN KINERJA KARYAWAN MELALUI MOTIVASI DAN KEPUASAN KERJA PDAM KECAMATAN EMPANG KABUPATEN SUMBAWA, NUSA TENGGARA BARAT
}

\author{
Sulaimiah \\ sulaimiahmia65@gmail.com \\ Universitas Mataram \\ Siti Nurmayanti \\ mayaramli24@unram.ac.id \\ Universitas Mataram
}

\begin{abstract}
Abstrak
Penelitian ini bertujuan untuk menguji pengaruh antara variabel Motivasi dan Kepuasan kerja terhadap Kinerja Karyawan "Studi Pada Perusahaan Daerah Air Minum (PDAM) Kec. Empang”. Jenis penelitian yang digunakan adalah penelitian Asosiatif Kausal. Populasi dalam penelitian ini adalah seluruh karyawan Perusahaan Daerah Air Minum (PDAM) Kec. Empang, yang berjumlah 210 responden dan Sampel penelitian berjumlah 68 responden dengan menggunakan rumus Slovin sebagai penentuan ukuran sampel dan teknik pengambilan sampel menggunakan metode Proportionate Stratified Random Sampling. Pengumpulan data di gunakan dengan angket dan dokumentasi .uji intrumen yang dilakukan dengan uji validitas, realibelitas dan uji asumsi klasikk yaituuji normalitas, mulitkolenaritas serta uji heterokedasitas. Data diuji dengan menggunakan teknik Analisis Uji Regresi Linier Berganda dengan menggunakan program IBM SPSS ver. 23. Hasil penelitian menunjukkan bahwa Motivasi berpengaruh positif dan signifikan terhadap Kinerja Karyawan dan Kepuasan kerja berpengaruh positif tidak signifikan terhadap Kinerja Karyawan Perusahaan Daerah Air Minum (PDAM) Kecamatan Empang, Sumbawa,Nusa Tenggara Barat

Kata Kunci: Motivasi ,kepuasan kerja, dan Kinerja Karyawan.
\end{abstract}

\begin{abstract}
This study aims to examine the effect of motivation and organizational commitment variables on employee performance. "Studies at Regional Drinking Water Companies (PDAM), Kec. Empang ". This type of research is causal associative research. The population in this study were all employees of the Regional Drinking Water Company (PDAM) Kec. Empang, which amounted to 210 respondents and the research sample was 68 respondents using the Slovin formula as the determination of the sample size and the sampling technique using the Proportionate Stratified Random Sampling method. The data were tested using the Multiple Linear Regression Analysis technique using the IBM SPSS version 23 program. The results of the analysis show that Motivation has a positive and significant effect on Employee Performance and satissfaction has a positive and significant effect on the Employee Performance of Regional Drinking WCompany (PDAM) Kec. Empang.

Keywords: Motivation, satissfaction and Employee Performe
\end{abstract}

Al Qalam: Jurnal Ilmiah Keagamaan dan Kemasyarakatan Vol. 16, No. 2

Maret - April 2022 
Sulaimiah, Siti Nurmayanti : Peningkatan Kinerja Karyawan Melalui Motivasi dan Kepuasan Kerja PDAM Kecamatan Empang Kabupaten Sumbawa, Nusa Tenggara Barat

\section{PENDAHULUAN}

Setiap organisa maupun perusahaan akan selalu berusaha untuk meningkatkan kinerja karyawan, dengan harapan apa yang menjadi tujuan perusahaan akan tercapai. Salah satu cara yang ditempuh oleh perusahaanmeningkatkan kinerja karyawannya, misalnya dengan melalui pendidikan, pelatihan, pemberian kompensasi yang layak, pemberian motivasi, enciptakan lingkungan kerja yang kondusif. ${ }^{1}$

Kinerja dapat dipengaruhi oleh beberapa faktor. Motivasi dan Kepuasan kerja merupakan bagian dari faktor-faktor yang dapat mempengaruhi kinerja. Motivasi dan kepuasan kerja memiliki arti penting dalam mempengaruhi kinerja karyawan. Faktor-faktor yang mempengaruhi kinerja, yaitu kemampuan dan keahlian,kepuasan, rancangan kerja,lingkungan ,kepemimpinan, budaya kerja , motivasi ,keperibadian, loyalitas, disiplin

Motivasi merupakan tingkah laku para karyawan yang bekerja dengan kondisi lebih optimal. Dengan kata lain, dengan memiliki motivasi yang tinggi, maka karyawan dapat menyelesaikan pekerjaan dengan hasil yang lebih baik, oleh karena itu motivasi mempunyai pengaruh terhadap kinerja setiap individu dalam organisasi.

Kepuasan kerja adalah adalah sikap yang positip dari tenaga kerja , meliputi perasaan dan tingkahl laku terhadap pekerjaan melalui penilaian salah satu pekerjaan sebagai rasa menghargai dalam mencapai salah satunilai-nilai penting pekerjaan.

Penelitian ini dilakukan karena adanya gap riset yang di temukan dari hasil penelitian sebelumnya yaitu menurut hasil peneliataian oleh Hendri dengan judul Pengaruh Semangat Kerja Terhadap Kinerja Pegawai Fakultas Ekonomi Universitas PGRI Palembang. ${ }^{2}$ Dengan hasil penelitian menunjukkan bahwa terdapat pengaruh yang signifikan antara variabel motivasi terhadap variabel kinerja pegawai.-Sementara hasil penelitian yang dilakukan oleh Rosmaini dengan judul pengaruh kompetensi, motivasi, kepuasan terhadap kinerja pegawai dinas perumahan rakyat Kota Tamiang Aceh ${ }^{3}$ yang menunjukkan hasil motivasi berpengaruh positif tapi tidak signifikan terhadap kinerja.

1 Bambang Guritno and Waridin, "Pengaruh Persepsi Karyawan Mengenai Perilaku Kepemimpinan, Kepuasan Kerja Dan Motivasi Terhadap Kinerja,” Jurnal Dinamika Manajemen 1, no. 1 (2005).

2 Edduar Hendri, "Pengaruh Semangat Kerja Terhadap Kinerja Pegawai Fakultas Ekonomi Universitas PGRI Palembang,” Jurnal Media Wahana Ekonomika 7, no. 2 (July 2010).

${ }^{3}$ Rosmaini, "Pengaruh Kompetensi, Motivasi Dan Kepuasan Kerja Terhadap Kinerja Pegawai Di Dinas Pekerjaan Umum Dan Perumahan Rakyat Kabupaten Aceh Tamiang” (Medan: UMSU, 2019).

Al Qalam: Jurnal Ilmiah Keagamaan dan Kemasyarakatan Vol. 16, No. 2

$$
\text { Maret - April } 2022
$$


Sulaimiah, Siti Nurmayanti : Peningkatan Kinerja Karyawan Melalui Motivasi dan Kepuasan Kerja PDAM Kecamatan Empang Kabupaten Sumbawa, Nusa Tenggara Barat

Penelitian ini adalah Perusahaan Daerah Air Minum (PDAM) Kec. Empang yang merupakan Badan Usaha Milik Daerah yang bergerak dibidang jasa penyediaan air bersih. Salah satu tujuan dibentuknya PDAM Kecamatan Empang adalah mencukupi kebutuhan masyarakat akan air bersih meliputi penyediaan dan pengembangan pelayanan di daerah Kecamatan Empang.Penelitian di laksanakan di sini karena terlihat hasil kerja karyawan belum seuai target yang di harapkan, dan adanya absensi yang belum optimal karena adanya karyawan yang tidak hadir tampa keterangan yang emngidikasi motivasi dan kepuasan karyawan masi belum optimal.Penelitian bertujuan Untuk mengetahui pengaruh positip signifikan motivasi terhadap kinerja karyawan Perusahaan Daerah Air Minum (PDAM) Kecamatan Empang dan untuk mengetahui pengaruh positif signifikan kepuasan kerja terhadap kinerja karyawan Perusahaan Daerah Air Minum (PDAM) Kecamata Empang, Sumabawa, Nusa Tenggara Barat.

\section{TINJAUAN PUSTAKA}

\section{Tinjauan Teoritis}

\subsection{Kinerja karyawan}

\section{a. Pengertian}

Rivai menyatakan "bahwa kinerja adalah hasil seseorang secara keseluruhan selama periode tertentu di dalam melaksanakan tugas, seperti standar hasil kerja, target atau kriteria yang telah ditentukan terlebih dahulu dan telah disepakati bersama". ${ }^{4}$

Dengan demikian kinerja merupakan suatu hasil dari suatu pekerjaan yang telah diselesaikan sesuai dengan tanggung jawab yang telah ditentukan. hal ini menunjukkan bahwa kinerja perlu dijadikan tolok ukur untuk membandingkan apa yang telah dilakukan dalam tanggung jawab yang telah diberikan.

\section{b. Faktor-faktor yang mempengaruhi kinerja karyawan}

Kinerja pada dasarnya mempunyai banyak faktor yang dapat berpengaruh. Faktor tersebut yang nantinya akan membuat kinerja yang dimiliki seseorang akan menjadi baik atau tidak. Adapun faktor-faktor yang mempengaruhi kinerja karyawan yaitu: Kemampuan, pengetahuan,rancangan kerja,kepribadian,motivasi kerja,budaya, kepemimpinan, kepuasan kerja,lingkungan kerja, loyalitas, komitmen,dispilin..

\section{c. Indikator penilaian kinerja}

Indikator yang digunakan untuk mengukur kinerja yang dilakukan dalam penelitian ini merupakan indikator yang mengatakan hampir semua cara pengukuran kinerja mempertimbangkan hal-hal sebagai berikut.

1. Kuantitas, yaitu jumlah yang harus diselesaikan atau dicapai. Pengukuran kuantitatif.

2. Kualitas, tingkat kepuasan, yaitu seberapa baik penyelesaiannya. Ini berkaitan dengan bentuk keluaran.

3. Ketepatan waktu, yaitu sesuai tidaknya dengan waktu yang direncanakan.

\subsection{Motivasi}

a. Pengertian

${ }^{4}$ Veithzal Rivai, Manajemen Sumber Daya Manusia Untuk Perusahaan (Jakarta: PT Raja Grafindo Persada, 2004).

Al Qalam: Jurnal Ilmiah Keagamaan dan Kemasyarakatan Vol. 16, No. 2

$$
\text { Maret - April } 2022
$$


Motivasi adalah sesuatu yang menyebabkan anda melangkah, membuat anda tetap melangkah, dan menentukan ke mana anda mencoba melangkah.

Motivasi adalah dorongan dasar yang menggerakkan seseorang bertingkah laku. Dorongan ini berada pada diri seseorang yang menggerakkan untuk melakukan sesuatu yang sesuai dengan dorogan dalam dirinya. Motivasi juga dapat dikatakan sebagai perbedaan antara dapat melaksanakan dan mau melaksanakan. Motivasi lebih dekat pada mau melaksanakan tugas untuk mencapai tujuan. ${ }^{5}$

b. Indikator Motivasi

Menurut Westra, tinggi rendahnya motivasi karyawan dalam suatu organisasi dapat diketahui melalui presensi, kerja sama, tanggung jawab dan kegairahan kerja. ${ }^{6}$

1. Presensi

2. Kerja sama

3. Tanggung Jawab

4. Kegairahan Kerja

\subsection{Kepuasan kerja}

Kepuasan kerja adalah perasaan positif seseorang terhadap pekerjaan yang dilakukan yang merupakan evalusi dari karakteristik pekerjaan,

\section{Indikator Kepuasan kerja}

Ada tiga komponen indikator kepuasan, yaitu: gaji,promosi, supervisi imbalan, pekerjaan itu sendiri,rekan kerja kebijakan organisasi

\subsection{Hubungan Antar Variabel}

Hubungan Motivasi, kepuasan dengan Kinerja Karyawan

Faktor-faktor yang mempengaruhi kinerja di antaranya Kedisiplinan, kemampuan, keterampilan, kepuasan, budaya kerja, komitmen, motivasi.

\section{Gambar 2.1 Kerangka Konseptual Penelitian}

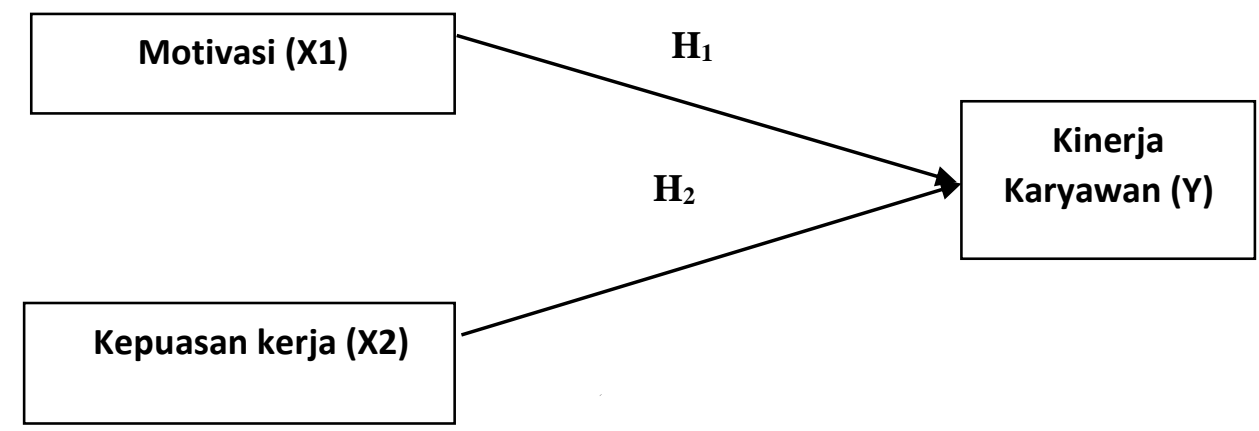

\section{METODE PENELITIAN}

\subsection{Jenis Penelitianda lokasi penelitian}

Jenis penelitian yang dingunakan dalam penelitian ini adalah penelitian kausal., Lokasi penelitian dilaksanakan di Perusahaan Daerah Air Minum (PDAM) yang

\footnotetext{
${ }^{5}$ Hamzah Uno, Teori Motivasi Dan Pengukurannya (Jakarta: PT. Bumi Aksara, 2011).

${ }^{6}$ P. Westra, Beberapa Masalah Dalam Hubungan Kerja Manusia Kemanusiaan (Yogyakarta: BPA UGM, 2010).
}

Al Qalam: Jurnal Ilmiah Keagamaan dan Kemasyarakatan Vol. 16, No. 2

$$
\text { Maret - April } 2022
$$


Sulaimiah, Siti Nurmayanti : Peningkatan Kinerja Karyawan Melalui Motivasi dan Kepuasan Kerja PDAM Kecamatan Empang Kabupaten Sumbawa, Nusa Tenggara Barat

beralamat di Jl. Lintas Sumbawa - Bima Kecamatan Empang Kabupaten Sumbawa,Nusa Tenggara Barat

\subsection{Populasi Dan Sampel}

Populasi dalam penelitian ini adalah karyawan PDAM Kec. Empang yang berjumlah 210 orang. Sampel penulis menggunakan teknik pengambilan sampel dari setiap bagian perusahaan adalah dengan cara Proportional Stratified Random Sampling Penentuan ukuran sampel menggunakan pendapat dari Slovin, yaitu dengan rumus: dihasilkan sampel sebanyak 68 orang.

\subsection{Teknik dan alat Pengumpulan Data}

Teknik yang dingunakan dalam penelitian ini yaitu :

Angket, dokumentasi,wawanca,serta alat Pengumpulan Data, kuesioner,panduan wawancara

\subsection{Jenis Dan Sumber Data}

Jenis data yang dingunakan dalam penelitian ini adalah data kualitatif yang akan di kuantitatifkan Sumber Data data primer dan data sekunder

\subsection{Identifikasi Variabel dan klasifikasi variabel}

Adapun identifikasi variabel-variabel pada penelitian ini adalamotivasi $\left(\mathrm{X}_{1}\right)$, kepuasan kerja $\left(\mathrm{X}_{2}\right)$ dan kinerja karyawan $(\mathrm{Y})$, klasifikasi variabelny. variabel bebas (independen variable) motivasi (X1) dan kepuasan kerja (X2) sementara variabel terikat (dependenriable) adalah kinerja karyawan (Y)

\subsection{Prosedur Analisis Data}

Sementar skala pengukuran menggunakan skor yang mengacu pada skala likert 5 ketuk dari sangat optimis sampai sangat pesimis, uji instrument, yaitu uji validitas, realibelitas dan uji asumsi klasik yeitu uji normalitas, uji multikoleneritas dan uji heterokedasitas di lengkapi dengan uji model yaitu uji F . Sementara uji hipotesa dengan menggunakan uji regresi linier berganda, yaitu uji $t$ dan untuk melihat besaran sumbangan variable bebas di dalam model di gunakan uji determinan simultan

\section{HASIL DAN PEMBAHASAN}

\section{1.. Karakteristik Responden}

Berdasarkan hasil dari kuesioner dapat diketahui karakteristik responden yang menjadi karyawan PDAM Kecamatan Empang ,Nusa Tenggara Barat sebagai berikut:

4.1.1. Jenis Kelamin. Karakteristik responden karyawan PDAM Kecamatan . Empang ,Sumbawa. Nusa Tenggara Barat dari 68 sampel responden berdasarkan jenis kelamin jumlah responden terbanyak di dominasi oleh karyawan dengan jenis kelamin laki-laki sebanyak 38 orang atau 55,9\% dan jenis kelamin perempuan sebanyak 30 orang atau 44,1\%.

4.1.2. Usia Hasil pengumpulan data primer diketahui usia responden yang dikategorikan menjadi 3 ketegori ,diketahui bahwa usia responden adalah usia dari 21-30 tahun sebanyak 13 orang $(19,1 \%)$, sedangkan usia 31-40 tahun sebanyak 35 orang $(51,5 \%)$ dan usia 41-50 Tahun sebanyak 20 orang $(29,4 \%)$. Karateristik responden berdasarkan usia didominasi oleh usia 31-40 tahun dan 41-50

Al Qalam: Jurnal Ilmiah Keagamaan dan Kemasyarakatan Vol. 16, No. 2

$$
\text { Maret - April } 2022
$$


4.1.3. Pendidikan diketahui bahwa tingkat pendidikan mayoritas responden adalah S1 sebanyak 42 orang $(61,8 \%)$, karena semakin tinggi tingkat pendidikan karyawan maka semakin baik tingkat pengetahuan karyawan serta kritis dalam memutuskan persoalan yang menyangkut pencapaian tujuan organisasi.

4.1.3. Variabel Penelitian. Dalam penelitian ini terdapat teknik analisa data untuk memberikan langkah langkah terkait data yang digunakan untuk diinterpretasikan. Fokus peneliatian ini adalah Kinerja Karyawan (Y),di dapatkan jawaban responden atas indikator kinerja karyawan dimana dari 68 responden dari rata-rata jawaban responden yang menunjukkan hasil 4,14. Sehingga dapat dikatakan karyawan PDAM Keamatan Empang, Sumabawa ,Nusa Tenggara Barat, memiliki tingkat kinerja karyawan yang tinggi. Untuk Motivasi di dapatkan rata-rata jawaban responden atas indikator Motivasi Kerja, dimana dari 68 responden yaitu karyawan PDAM Kecamatan Empang, Sumabawa, Nusa Tenggara Barat, menunjukkan bahwa motivasi kerjanya tinggi, hasil rata-rata 4,16. Sehingga dapat dikatakan karyawan PDAM Kecamatan Empang,Sumabawa Nusa Tenggara Barat memiliki motivasi kerja yang tinggi. Variabel Kepuasan kerja (X2) memperlihatkan jawaban responden, dimana dari 68 responden yaitu karyawan PDAM Kecamatan Empang menunjukkan bahwa kepuasan sangat bagus, ini terlihat dari rata-rata jawaban responen 4,30. Sehingga dapat dikatakan karyawan PDAM Kec. Empang memiliki kepuasan kerja yang sangat bagus.

4.2. 1 Hasil Uji Validitasdan

Dari hasil uji validitas semua item pertanyaan dari masing-masing variable menunjukkan hasil semuanya valid karena $r$ hitung $>0,3$ baik variable motivasi, kepuasan maupuan kinerja.

\subsubsection{Hasil Uji Reliabilitas Variabel}

Hasil uji reliabilitas variabel Kinerja Karyawan, Motivasi, dan kepuasan kerja menggunakan program SPSS, semua menunjukkan alpha Cronbach $>0,6$, jadi semua variable realibel

\subsubsection{Hasil Uji Asumsi Klasik dan Uji Model}

Sebelum analisis regresi, uji t dilakukan, terlebih dahulu dilakukan pengujian yang meliputi uji normalitas, multikolinearitas, dan heteroskedastisitas, semua instrument yang di gunakan baik motivasi, kepuasan kerja dan kinerja semuanya memenuhi stadar uji asumsi klasik baik uji normalitas, multikoleneritas dan uji heterokedasitas, serta di lengkapi uji model yaitu uji $\mathrm{F}$, dimana semua variable bebas dapat di gunakan untuk memprediksi perubahan kinerja.

\subsection{Hasil Uji Analisis Regresi Linier Berganda}

Analisis regresi linear berganda bertujuan untuk mengetahui pengaruh Motivasi dan Kepuasan terhadap Kinerja Karyawan PDAM Kecamatan Empang, Sumabawa , Nusa Tenggara Barat. Hasil Pengujian dengan menggunakan analisis regresi liniear berganda pada program SPSS didapatkan

$$
\mathrm{Y}=1,524+0,541 \mathrm{X}_{1}+0,086 \mathrm{X}_{2}+\mathrm{e}
$$

\subsubsection{Uji t Parsial}

Uji ini di gunakan untuk mengetahui apakah dalam model regresi variabel independen (motivasi dan kepuasan kerja) secara parsial berpengaruh terhadap variabel dependen (kinerja) dan digunakan untuk hipotesis yang di ajukan, nilai thitung variabel motivasi di peroleh nilai $t_{\text {hitung }}>$ $t_{\text {tabel }}(7,188>1,99714)$, menunjukan bahwa motivasi mempunyai hubungan yang searah dengan kinerja karyawan. Jadi dapat di simpulkan motivasi kerja berpengaruh positif dan signifikan secara parsial terhadap kinerja karyawan PDAM Kecamatan Empang, Hal ini se jalan dengan

Al Qalam: Jurnal Ilmiah Keagamaan dan Kemasyarakatan Vol. 16, No. 2

$$
\text { Maret - April } 2022
$$


Sulaimiah, Siti Nurmayanti : Peningkatan Kinerja Karyawan Melalui Motivasi dan Kepuasan Kerja PDAM Kecamatan Empang Kabupaten Sumbawa, Nusa Tenggara Barat

teori kasmir bahwa motivasi berpengaruh terhadap kinerja dan juga sejalan dengan penelitian yang dilakukan oleh Juniantara I wyn yang menghasilkan penelitian yang sama dengan penelitian ini. Demikian juga hubungan kepuasan kerja $(X 2)$ di peroleh nilai $t_{\text {hitung }}<t_{\text {tabel }}(0,862<1,99714)$ dapat di simpulkan Kepuasan kerja berpengaruh positif dan tidak signifikan terhadap kinerja, ini sejalan dengan hasil penelitian yang dilakukan oleh Aida Mutia yang menhasilkan penelitian kepuasan kerja berpengruh positif tidak signifikan.

Keofisien determinasi $\left(\mathrm{R}^{2}\right)$ pada mengukur seberapa jauh kemampuan model dalam merangkakan variasi variabel dependen. Pada penelitian ini angka Adjusted R-Square sebesar $0.535(53,5 \%)$. Ini berarti bahwa pengaruh variabel bebas terhadap variabel terikat adalah $53,5 \%$, dan sisanya sebesar 46,5\% (100\% - 53,5\%) dapat dijelaskan oleh faktor-faktor lainnya yang tidak diteliti oleh penelitian ini, seperti disiplin kerja, lingkungan kerja, fasilitas kerja, kepuasan kerja, pelatihan, stress kerja, insentif, kompensasi, dan lain sebagainya.

\section{KESIMPULAN}

Berdasarkan hasil kajian setelah menganalisis dan menguji pengaruh Motivasi, dan Komitmen Organisasional terhadap Kinerja Karyawan PDAM Kecamatan Empang,Sumbawa, Nusa Tenggara Barat maka dapat di simpulkan sebagai berikut:

1. Variabel Motivasi berpengaruh positif dan signifikan terhadap Kinerja Karyawan PDAM Kecamatan Empang Sumbawa, Nusa Tenggara Barat

2. Variabel Kepuasan berpengaruh positif namun tidak signifikan terhadap Kinerja Karyawan PDAM Kecamatan Empang, Sumbawa, Nuasa Tenggara Barat.

\section{SARAN}

Berdasarkan untuk kepentingan praktisi maupun kepentingan organisasi perlu disampaikan beberapa saran sebagai berikut:

Untuk meningkatkan Kinerja Karyawan PDAM Kecamatan Empang ,Sumabawa Nusa Tenggara Barat perlu menciptakan kesadaran diri untuk senang membantu rekan kerja yang mengalami kesulitan dalam bekerja berimbas pada efektifitas kerja karyawan kemudian meningkatkan motivasi seperti evaluasi dari atasan terhadap kemajuan kinerja

Diharapkan bagi peneliti selanjutnya untuk meneliti variabel-variabel lain yang mempengaruhi Kinerja Karyawan seperti halnya Budaya Organisasi, Pelatihan, kepemimpinan, komitmen, disiplin, dan lain sebagain

\section{DAFTAR PUSTAKA}

Guritno, Bambang, and Waridin. "Pengaruh Persepsi Karyawan Mengenai Perilaku Kepemimpinan, Kepuasan Kerja Dan Motivasi Terhadap Kinerja." Jurnal Dinamika Manajemen 1, no. 1 (2005).

Hendri, Edduar. "Pengaruh Semangat Kerja Terhadap Kinerja Pegawai Fakultas Ekonomi Universitas PGRI Palembang." Jurnal Media Wahana Ekonomika 7, no. 2 (July 2010).

Rivai, Veithzal. Manajemen Sumber Daya Manusia Untuk Perusahaan. Jakarta: PT Raja Grafindo Persada, 2004.

Al Qalam: Jurnal Ilmiah Keagamaan dan Kemasyarakatan Vol. 16, No. 2

Maret - April 2022 
Sulaimiah, Siti Nurmayanti : Peningkatan Kinerja Karyawan Melalui Motivasi dan Kepuasan Kerja PDAM Kecamatan Empang Kabupaten Sumbawa, Nusa Tenggara Barat

Rosmaini. 2019. Pengaruh Kompetensi, Motivasi Dan Kepuasan Kerja Terhadap Kinerja Pegawai Di Dinas Pekerjaan Umum Dan Perumahan Rakyat Kabupaten Aceh Tamiang. Prodi Magister Manajemen Universitas Muhammadiyah Sumatera Utara. Medan

Uno, Hamzah. Teori Motivasi Dan Pengukurannya. Jakarta: PT. Bumi Aksara, 2011.

Westra, P. Beberapa Masalah Dalam Hubungan Kerja Manusia Kemanusiaan. Yogyakarta: BPA UGM, 2010.

Al Qalam: Jurnal Ilmiah Keagamaan dan Kemasyarakatan Vol. 16, No. 2

Maret - April 2022 